\title{
Seçmenlerin 0y Tercihlerinin Belirlenmesinde Etkili Faktörler ve Aday İmajının Bu Süreçteki Etkisi: 31 Mart 2019 Yerel Seçimleri Sivas Örneği
}

\author{
Onur Taydaş (Dr. Öğr. Üyesi) \\ Sivas Cumhuriyet Üniversitesi İletişim Fakültesi \\ onurtaydas@hotmail.com
}

Başvuru Tarihi: 03.09.2020

Yayına Kabul Tarihi: 02.12.2020

Yayınlanma Tarihi: 29.01.2021

https://doi.org/10.17680/erciyesiletisim.789797

\section{Öz}

Çalışmada seçmen davranışlarında etkili olan faktörlere bakılarak bu tutumun şekillenmesinde başat etkenler incelenmiştir. 31 Mart 2019 Sivas Seçimlerinde seçmenin adaylara karşı olan tutumları nitel araştırma yöntemlerinden anket yöntemi ile değerlendirilmiştir. Çalışmada Sivas ilinde rastgele seçilen 537 kişiyle oluşturulmuştur. Anket uygulamasına 5 Nisan tarihinde başlamış 30 Nisan 2019 tarihinde tamamlanmıștır. Basit tesadüfi örnekleme yöntemi ile seçilen deneklere ilk bölümde beşli likert ölçeği ile hazırlanmış 20 adet soru sorulmuştur. İkinci bölümünde çalışmaya katılanların siyasal tutum ve davranışlarının belirlenmesine yönelik sorular yönetilmiştir. Anketin üçüncü bölümünde bireylerin siyasal konulardaki bilgi düzeylerini anlamak için hazırlanan sorular sorulmuş olup, dördüncü bölümde ise katılımcıların demografik özelliklerini saptamak amacıyla kişisel sorulara yer verilmiştir. Çalışmada adayı imajı özelinde; adayın siyasi partisi, adayın mensup olduğu çevre, siyasi konjonktür, medya gibi faktörlerin seçmen kararlarına etkisinin ölçülmesi amaçlanmıştır. Elde edilen sonuçlara göre, katılımcıların aile ve sosyal çevrelerinin etkisi altında kararlarını belirleme düzeyleri yașlara göre değişmektedir. Araștırmada dikkat çekici bulgulardan biri de gazete, radyo gibi geleneksel medya ürünlerinin sosyal medyaya nazaran seçmen tercihinde azalan etkisidir.

Anahtar Kelimeler: İletişim, Aday İmajı, Yerel Seçimler, Seçmen Davranışı, Siyasal İletişim. 


\title{
Effective Factors on Determining the Voting Preferences of Voters and the Effect of Candidate Image on this Process: 31 March 2019 Sivas Local Elections Example
}

\author{
Onur Taydaş (Asst. Prof. Dr.) \\ Sivas Cumhuriyet University Faculty of Communication \\ onurtaydas@hotmail.com
}

Date Received: 03.09.2020

Date Accepted: 02.12.2020

Date Published: 29.01.2021

https://doi.org/10.17680/erciyesiletisim.789797

\begin{abstract}
In the study, the dominant factors were examined by looking at factors that affect voter behavior. On March 31, 2019, in Sivas Elections, the attitudes of the voters towards the candidates were evaluated with the survey method. The study was created with 537 randomly selected people. The survey application started on April 5, 2019, and was completed on April 30, 2019. In the first part, 20 questions prepared with a five-point Likert scale were asked to the subjects selected by simple random sampling method. In the second part, questions were directed to determine the political attitudes and behaviors and in the third part to understand the knowledge levels of individuals on political issues, and in the fourth part, to determine the demographic characteristics of the participants. In terms of candidate image, it is aimed to measure the effects of factors such as political party, the environment of the candidate, political conjuncture, and media on voter decisions. According to obtained results, the level of determining decisions under the influence of family and social environment varies according to the ages. One of the striking findings is the decreasing effect of traditional media products such as newspapers and radio on voter choice compared to social media.
\end{abstract}

Keywords: Communication, Candidate Image, Local Elections, Voter Behavior, Political Communication. 


\section{Giriş}

İktidar aşkı insanın en güçlü motivasyonlarından biridir. Buna rağmen toplumlar iktidar bakımından farklı șekillerde birbirinden ayrıșmaktadır. Aynı zamanda bireylerin veyahut örgütlerin sahibi oldukları alanlara göre de iktidar çeşitlilik göstermektedir. Askeri despotizm, teokrasi, plütokrasi gibi birçok örgütsel sistemde devlet iktidarı eskiye oranla kendisini daha fazla hissettirmektedir. Aynı zamanda iktidar elde ediliş yöntemine göre de toplumsal farklılıklara tabidir. Hanedanlığa dayalı yüksek bir kişinin iktidara erişme yöntemi, toplumun genelinin inanç sistemiyle paralel büyük bir din adamının aranması ya da savaş ve demokrasidir (Russell, 2014, s. 17). Demokrasi modern toplumların birçoğu tarafından benimsenen yönetim şekli olarak karşımıza çıkmasına rağmen, tarihi yaklaşık olarak günümüzden 2500 yıl öncesine dayanmaktadır. Grekçe halk veya halka ait anlamına gelen "demos" ve egemen olmak, iktidar olmak, yönetmek anlamlarını içeren "kratein" kelimelerinin birleşmesiyle oluşmaktadır. Ortaya çıkan yeni kelime yani demokrasi kısaca halkın egemenliği ya da çoğunluğun yönetimi olarak vücut bulmaktadır (Schimdt, 2001 Akt. Dursun, 2016, s. 163-165).

Bu noktadan sonra ise karşımıza halkın ya da bir devlet içerisindeki çoğunluğun iktidara nasıl, ne kadar süreyle, ne kadar yetkiyle sahip olacağı soruları çıkmaktadır ki; bu soruların cevapları siyaset biliminin asıl konusudur. Çünkü çok farklı tanımlamaları olmasına karşın genel olarak ele alındığında Bismarck'ın deyimiyle siyaset bir bilim olmaktan öte bir sanattır ve bu sanat toplumun kontrol edilmesi, ortak kararların alınmasının yanı sıra alınan kararların uygulanması ile de ilgilidir. 0 halde siyaset en temelinde insanlar arasında gerçekleșen sosyal bir mesele olarak ele alınmaktadır. Bir bașına ıssız bir adada yaşayan Robinson Crouse örneğine bakacak olursak, karar almasında ya da kararından geri durmasında onu engelleyecek veya destekleyecek kendi dışında ikinci bir irade Cuma'nın gelişine kadar bulunmamaktadır. İstediği kararları istediği çabuklukta alıp uygulamaya koyan Robinson Crouse siyasetten de bihaber olduğu kadar siyasete de ihtiyacı yoktur (Heywood, 2018, s. 64). Ancak modern toplumlarda hiç kimsenin birer Robinson Crouse olamayacağı gerçeğinden hareketle siyasetten de uzak kalamayacağını bilmek gerekir. Bu nedenledir ki siyaset günümüzde toplumun yönetilmesine ek olarak kamu düzeninin sağlanması/sürdürülmesi (Kaya, 2011, s. 17) anlamlarını da içeren bir iktidar mücadelesidir. Belki de siyasetin bir iktidar mücadelesi olarak anılmasının temel nedeni sosyal yaşamdaki zıtlıkların çatışması ve siyasetin bu karşıtlıkları belli bir noktada birleştirmeye çalışmasıdır (Dursun, 2016, s. 33).

Sorunların çözümü ve karşıtlıkların uzlaştırılması sürecinde ise bütün sorumluluk siyasal alanın aktörlerine düşmektedir. Liderler, baskı grupları, siyasal partiler, seçmenler, hükümetler, sivil toplum örgütleri vd. olmak üzere çok farklı gruplar ya da kişiler bu aktörler arasında yer almaktadır.. Sözü edilen tüm bu aktörler siyasal iktidarın belirlenmesinde etkindir. Siyaset bu anlamda siyasal aktörler arasında gerçekleştirilen bir iletişim süreci olarak da düşünülebilir. Sözü edilen süreç ne derece başarılı bir şekilde işletilirse iktidarın elde edilmesi de o derece kolay olmaktadır. Fakat buradaki temel sorun iktidara giden yolda ve sonrasında tüm bu aktörlerin kimin etrafında kümeleneceğidir. Çünkü temsili demokrasilerde halk kendisini yönetmesi için bir siyasal parti liderine ya da bir adaya oy vermek zorundadır.

Seçmenlerin bir vatandaşlık görevi olarak kendilerine yüklenen oy kullanma eylemini gerçekleştirirken nasıl karar verdiklerini anlamak amacıyla üç model geliştirilmiştir. Bunlardan birincisi seçmenlerin kendi çıkarlarını iyi bilmesi ve bu çıkarlara en iyi hizmet edeceğini düşündügü adaya ya da lidere yöneldiğini söyleyen rasyonel (ekonomik) 
yaklaşımdır (Kalender, 2000, s. 50). İkincisi psikolojik ya da partiye özdeşleşme olarak bilinen seçmenlerin siyasal partiye dair tutumları, siyasal hayatı algılamaları (Doğan, 2017, s. 80) ve buna ek olarak bir partiye olan bağlıklarının ön planda tutulduğu yaklaşımdır. Sosyolojik yaklaşım ise küçük gruplar arasındaki iletişim ve etkileşimi karar verme sürecinin önemli bir öğesi olarak görmektedir. Dolayısıyla küçük gruplar arasındaki arkadaşlık ve birliktelik duygusu artınca bu gruba ait bireyler eleştirel bakıştan uzaklaşmakta, kolektif bir bilinçle hareket etmektedir (Köni, 1982, s. 96-97). Bunların dışında, toplumdaki egemen görüşle birlikte, hakim ideolojiyle paralellik gösterecek şekilde ve gündemdeki konulara göre seçmenlerin oy verme kararlarını belirlediğine yönelik yaklaşımlar bulunmaktadır.

Ancak seçmenlerin oy verme kararlarını yukarıda adı geçen yaklaşımın dışında siyasal parti liderlerine ya da adaylara göre de şekillendirdikleri bilinmektedir. Bu nedenle de seçimlere katılan adayların imajları seçmenler açısından büyük önem arz etmektedir. Adayların hatta siyasal partilerin sergiledikleri davranışlar seçmenlerin tercihlerini belirlemede önemli bir yere sahiptir. Bu nedenle de seçimlere katılan adayların imajları seçmenler açısından önemli bir güce sahiptir. Baudrillard klasik anlamda politik örgütleri güçlendirmenin yerini temsillerin aldığını savunmaktadır. Ona göre artık klasik siyaset son bulmaktadır. Klasik siyasetin yerini temsiller almakta, temsillerde insanlar düşüncelerini bulmakta ya da birileri tarafından bu düşünceler yönetilmektedir (2006, s. 18-19). Dolayısıyla temsiller hedef kitlelerin algılarını yönlendirme amacıyla kullanılmaktadır. Seçimlere katılan adayların imajlarının da seçmenlerin tercihlerinde büyük önem taşıdığı düşünülmektedir. Özellikle de yerel seçimler bu anlamda büyük önem taşımaktadır. Çünkü seçmenler yerel seçimlerde oy verebileceği adayları yakından takip edebilmektedir. Dolayısıyla bu gerekçeyle 31 Mart 2019 Yerel Seçimlerinde seçmen tercihlerinde önemli bir yeri olduğu düşünülen aday imajlarının, yerel seçimlere katılan seçmenlerin kararları üzerindeki etkisinin ölçülmesi amaçlanmıştır.

Çalışmada 31 Mart 2019 yerel seçimlerinde Sivas ili merkez sınırları içerisinde oy verme hakkına sahip bireyler ana kütle olarak seçilmiştir. Araştırmanın örneklemi tesadüfi yöntem ile belirlenmiştir. Veriler, Sivas ilinin çeşitli yerlerinde rastgele seçilen bireylerle yüz yüze görüşerek uygulanan 537 anket aracılığıyla toplanmıştır. Anket uygulaması seçimlerden sonraki hafta olan 5 Nisan tarihinde başlamış - 30 Nisan 2019 tarihleri arasında tamamlanmıştır. Yapılan çalışmada birinci olarak seçmenlerin, adayların hangi özelliklerine göre oy tercihlerini belirlediklerine ve sosyal medyanın seçmen tercihlerine nasıl bir etkisinin olduğunu saptamak amacıyla tasarlanmıştır. İkinci olarak ise genel olarak seçmenlerin oy tercihlerini belirleyen faktörler üzerine odaklanılmıștır. Ayrıca çalışma sonucunda elde edilen veriler seçmen karar tercihinde etkili faktörlerin neler olduğuna yönelik literatüre katkı sağlamaktadır

\section{İmaj Kavramı}

İmaj kelimesinin 13. yüzyıldan itibaren fiziksel bir suret ya da benzerlik anlamına gelen şekliyle kullanılmaya başlandığı bilinmektedir. Latince imago kök sözcüğünün en eski anlamları olan hayalet, kavram ya da düşünce anlamlarını da ihtiva etmektedir. Taklit etmek anlamına gelen Imatate sözcügüyle de yakın bir bağlantısı bulunmaktadır. Ancak 17. Yüzyılla birlikte fiziksel anlamı geliştirilerek edebiyat eserlerindeki bir figürü tanımlamak amacıyla da kullanılmaya başlamıştır. Reklamcılık ile birlikteyse image kelimesi markaların imajları ya da siyasi figürlerin kendilerine dair düşüncelerin toplamıyla birlikte kısaca insanlar tarafından algılanan şöhret şeklinde kullanılmaya başlamıştır (Williams, 2007, s. 190). 
Türkçede ise imaj kelimesinin kökeni genellikle Fransızcadaki image kelimesine dayandırılmakta ve kısaca "genel görünüm, izlenim" anlamlarına karşılık gelmektedir. Diğer taraftan imaj kelimesi, "duyularla bir uyaran söz konusu olmaksızın bilinçte beliren nesne ya da olaylar" veyahut "duyu organlarının dıștan algılandığı bir nesnenin bilince yansıyan benzeri ya da hayali" şeklinde açıklanmaktadır (TDK, 2009, s. 963). Dolayısıyla imaj insanların tamamını sonradan yarattıkları bir şey değildir. Aksine imaj bireylerin belli konulardaki birikimleri ve tercihlerinin tutarlı bir yansımasıdır. Bu nedenle de imaj hedef kitle üzerinde tamamen olumlu bir hava yaratmak için girişilen bir çaba olarak da karşımıza çıkmaktadır (Çobanoğlu, 2007, s. 206). Ayrıca imaj bir konunun tanıtılması ve benimsetilmesinde de büyük yer tutmaktadır (Bülbül, 2004, s. 8). Bahsi geçen bu tanıtma ve benimsetmeyle birlikte gerçeklik, fiziksel ya da imgelemsel olarak insanların belleklerinde yer tutmaya başlamaktadır (Mutlu, 2008, s. 154). İmaj bir kurum için fiziksel görüntüyü, kurumsal iletişimi ve kurumsal davranışı, birey için düşünüldügündeyse, dış görünüm, beden dili, davranış şekli, bireyin içinde bulunduğu ortam ve bireyin davranış şekli gibi çok geniş bir alanı kapsamaktadır (Peltekoğlu, 2014, s. 572).

Bireylerin bilgi, deneyim ve görünüş gibi birçok farklı özelliğine göre iyi-kötü benzeri sıfatlar kazanan imaj belli bir süreç sonucu kazanılan bir edimdir. İmaj, konuyla ilgili olarak insanların belleklerinde oluşan işte bu tasvirdir. Bu tasvir belli bir noktadan sonra halkla ilişkiler ve reklamcılık alanına ait bir kavram olarak karşımıza çıkmaktadır. Özellikle başta televizyon olmak üzere görselliğin ön planda olduğu kitle iletişim araçlarının artmasıyla birlikte imaj kavramına daha geniş pencerelerden bakılmaya başlanmıştır. Edebiyat ve resim başta olmak üzere imaj kavramı 20. yüzyılla birlikte halkla ilişkiler, reklamcılık ve siyaset olmak üzere manipülatif süreçlerin desteklenmesi amacıyla da kullanılmaya başlanmıştır (Williams, 2007, s. 190). Bu manipülatif süreçte temel araç medyadadır. Medya imaj oluşturma sürecinde kamuoyunda ortak bir fikir oluşturmak, imajın yaygınlaşmasını sağlamak ve itibar oluşumuna katkı vermek amacına yönelik olarak kullanılmaktadır. Bu nedenle imaj oluşturmada medya ve medyanın yönetimi büyük önem arz etmektedir (Gencer, 2020, s. 353). Diğer taraftan bu yönetim yapılırken sıklıkla bir parlatma yöntemi seçilmekte, insanların ya da kurumların olumsuzlukları gizlenmekte, kimi zaman ise var olmayan bir konu sanki varmışçasına gösterilmektedir (Türkkahraman, 2004, s. 5). İmaj bu anlamda bir makyajlama tekniği olarak da ele alınabilmektedir. Sözü edilen makyaj çalıșmalarının en hassas yapıldığı ve en kırılgan olduğu yer olarak ise karşımıza siyaset çıkmaktadır. Özellikle seçimler öncesi liderlerin ve adayların imajlarının seçmenlerin tercihleri üzerinde etkili olduğu bilinmektedir. Seçmenlerin yerel seçimlerdeki adaylarla olan yakınlığı düşünüldüğünde adayın imajının seçim üzerindeki etkisinin önemli olduğu gerçeği ortaya çıkmaktadır.

\section{Aday İmajı ve Yerel Seçimler}

Seçmenlerin oy verme sürecinde kararlarını etkileyen çok farklı parametreler ve bu parametreleri açıklamaya yönelik farklı yaklaşımlar bulunmaktadır. Fakat karmaşık yapısı olan insan davranışlarının seçim sürecindeki şekilleniş biçimi herkesin kabul edeceği üzere tek bir nedene bağlanamamaktadır. Seçmenlerin, özellikle oy kullanım eylemini gerçekleştirene kadar farklı etkenler kararlarını etkileyebilmektedir. Bahsi geçen bu etkenlerden biri de oy kullanacağı adayın imajıdır. Çünkü yerel seçimlerde seçmen, sosyolojik, rasyonel, psikolojik, konuya oy verme ve ideolojik yaklaşımların dışında kararını verirken bulunduğu yerdeki adayla olan yakınlığını, iletişimini kimi zamanda adayın yereldeki imajını hesaba katmaktadır. $\mathrm{Bu}$ nedenle de normalde hiçbir zaman oy vermediği bir siyasal partiye kimi zaman sırf yerelde gösterdiği 
aday nedeniyle de oy verebilmektedir. $\mathrm{Bu}$ partinin gösterdiği adayın seçmenler üzerindeki etkisinin anlaşılması bakımından önemlidir. Zira yerel seçimlerde seçmen tercihinde adaylar belirgin bir şekilde seçmen kararlarında etkili olabilmektedir (Doğan \& Göker, 2010, s. 160).

Diğer tüm imaj çalışmalarının temel özelliği gibi aday imajı da belli bir birikim sonucu oluşturulmaktadır. Sözü edilen bu birikim insanın içinde bulunduğu kültürün yansıması şeklinde vücut bulmaktadır (Çobanoğlu, 2007, s. 206). Nitekim aday imajı bu bağlamda adayın dışa dönük bir sunumudur. Bellekte yer alan bir yapıdır. Buna rağmen imajın siyasetçiler tarafından belirlenmesi ve kullanılması süreci ilk kez halkın siyasetten yavaş yavaş uzaklaşmaya başlaması, ikinci olarak ise siyasetin medyaya ve oradaki ünlülere yönelmesiyle birlikte olmuştur. Siyasetçilerin imajı bu anlamda kamuda psikolojik etki yaratmak ve medyada yer alabilmek amacıyla kullanmaya başladıkları bir gerçektir. Bunu başarabilmek adına kişilikleriyle ilgili kimi zaman gizli kalması tercih edilen bazı bilgileri de açıkladıkları bilinmektedir (Lilleker, 2006, s. 129-130). Bunların dışında imajların özellikle Türkiye'de merkez sağ ve sol partilerin söylemleriyle üretildiği de bilinmektedir. Bilhassa merkez partiler kendilerini diğerlerinden ayıran tüm özelliklerini imajlar üzerinden kurmaktadır (Çobanoğlu, 2007, s. 210). Siyasal partilerin seçimlerde aday gösterdikleri kişilerinde bu söylemlerle birlikte olarak imajlarını şekillendirdikleri görülmektedir.

Diğer taraftan aday imajları özellikle yerel seçimlerde partinin lideri etrafına konumlandırılmaktadır. Bu durum seçmenlerin partiye oy verme yaklaşımlarını sergileyecekleri düşüncesinin yanı sıra partinin tüm ülkede sürdürdügü seçim kampanyalarının devamlılığı açısından da önem arz etmektedir. Yerel seçimlerde sürdürülen tüm kampanya materyalleri bu anlamda birlik göstermektedir. Son yıllardaki seçimlere dikkat edildiğinde adayların seçim afişleri, posterleri vd. tüm seçim için kullandığı görsel malzemelerde, hatta kimi zaman bu görsellerde kullandıkları kıyafetler dahi liderlerinin kıyafetleriyle benzeșim göstermektedir. Belki de yerel yönetimlerde belediye yöneticisinin şehrin hangi sorunlarıyla ilgilendiğine ya da şehre ait hangi sorunlara eğildiğine değil, bunların aksine hangi partiye mensup olduğuna bireylerin odaklanması bu durumu özetlemektedir (Çukurçayır, 2012, s. 136). Fakat her ne kadar parti özelinde aday bir değerlendirmeye tabi tutulsa dahi, adayın karakteri, başarısı, iletişim becerileri, mevcut siyasi konjonktürün durumu, medya ve medyanın adaya olan bakışı ve çevresel eğilim gibi birçok etken de en az adayın partisi kadar seçmenin kararında etkili olabilmektedir.

\section{Adayın Karakteristik Özellikleri}

Adayın karakteristik özellikleri seçmenin adayı seçme noktasında önemli etkenlerden biridir. Seçim kampanyaları bu etkenler de hesap edilerek hazırlanmaktadır ve adayların bazı özelliklerinin makyajlanarak seçmenlere sunulması, onların belleklerindeki aday imajlarının daha da sağlamlaşması amacını taşımaktadır. Bundan dolayıdır ki; adaylar için seçmenlere sunulacak olan imajların kamuoyundaki yansıması büyük önem arz etmektedir. Öyle ki bu durum seçmenler üzerindeki sınırlı etkisi olduğu bilinen adayların kıyafetleri, saç stilleri hatta makyajlarını dahi kapsamaktadır (Ural, 2002). Lakin sözü edilen bu faktörler tek başlarına seçmenlerin kararlarını etkileme konusunda yeterli değildir. Bu nedenle de görselliğe dayalı imajın seçmenlerin duygularına hitap edilecek şekilde desteklenmesi gerekmektedir. Nitekim seçmenler karşılarına seçilme ümidiyle çıkan adayın dürüst, güvenilir, zeki olmasını önemsemektedir. Bu özellikleri taşıdığına inandıkları adayların seçimleri kazanma olasılığı büyüktür. Siyasal seçimlerde adayların 
imajları olarak sadece görsel özellikleri akla gelmektedir. Ancak imaj adayın görsel özelliklerinin yanı sıra konuşması, başarıları hatta duygusal tüm özelliklerinin seçmenin belleğinde oluşturduğu algıdır. Bu nedenle de siyasetteki başarının yarısı seçmeni ikna etme kabiliyeti diğer yarısı da imajın başarılı bir şekilde oluşturulması ve korunmasıdır. Sözü edilen bu amaçla birlikte adaylar için seçmenleri ikna edebilecekleri birer imaj oluşturulur, kitle iletişim araçları ve seçim kampanyaları aracılığıyla da seçmenler sunulur. Bu noktada imajın yönetilmesi seçim kampanyalarının önemli bir görevi konumundadır. Zira seçimlere katılan adayların karakteristik özellikleri, diğer insanlarla olan iletişim kabiliyetleri, mizaçları, yönetim becerileri, iş yaşantısındaki başarıları, kamudaki ve bürokrasideki deneyimleri, eğitim dereceleri, zekâ düzeyleri hatta huyları dahi imajları açısından büyük önem taşımaktadır (Balcı, 2003, s. 153). Dolayısıyla seçmenlerin zihinlerinde adayla ilgili pozitif bir algının oluşturulması amaçlanmakta, sürekli adayla ilgili iyi şeyler kampanyalar boyunca sunulmakta, adayın olumsuz sayılabilecek davranışları varsa başarısızlıkları gizlenmeye çalışmakta, hatta adayın seçim kampanyası boyunca davranışları da sürekli kontrol edilmektedir.

\section{Adayın Siyasi Partisi}

Siyasi partiler, bir program çerçevesinde siyasi kararları etkilemek ve bu amaçla siyasal iktidarı ele geçirmek üzere örgütlenmiş kuruluşlardır (Kışlalı, 2018, s. 277). Aday imajının oluşumunda etkili olan ana etmenlerden birisi de adayın bağlı olduğu siyasal partidir. Seçmenler tercihlerini yaparken geleneksel bazı kıstasları da göz önünde bulundururlar. Belki de burada dikkat edilmesi gereken en önemli unsur adayın mensubu olduğu siyasal parti hatta o partinin ideolojisidir. Kalender (2000, s. 157-158) seçmenlerin bir şekilde karar süreçlerinde adayların parti ideolojilerinin etkili olduğunu yaptığı çalışmasında açıklamıştır. Dolayısıyla seçmenleri ikna etmeye yönelik yapılan çalışmalarda siyasal parti ve partinin savunduğu ideolojiye de yer verilmesi gerekmektedir.

\section{Adayın Başarıları}

Adayların imajlarının oluşturulması için büyük çaba harcanmaktadır. Bilindiği üzere adayların imajları üzerine çalışırken üstünde önemle durulan bir konuda başarıdır. Özellikle kampanya tasarlayıcıları tarafından hazırlanan imajların olumlu bir şekilde seçmeni etkilemesi için adayın geçmişten kampanya dönemine kadar kazandığı başarılara odaklanılmaktadır. Bilhassa yerel seçimlerde bu konuya biraz daha farklı yaklaşılmaktadır. Zira yerel seçimlerde aday olarak seçmen karşısına çıkan bireylerin geçmiş yaşantılarında kazandıkları başarılar kadar, zaten başarılı olarak yürütmekte oldukları bir göreve yeniden talip olmaları onların imajları açısından büyük önem arz etmektedir (Damlapınar \& Balcı, 2014, s. 128). Adayın mevcut konumunu sağlamlaştıran başarılar, adaya seçmen nezdinde güçlü bir lider imajı kazandırır. Ancak yerel seçimler özelinde düşünüldüğünde güçlü bir lider imajı kadar etkili bir diğer hususta "hizmette lider" rolünün üstlenilmesidir. Çünkü seçmenler yerel seçimlerde oy verecekleri adayların "politik lider" olma vasıflarından çok kendileri için nasıl hizmet edeceği kısmına odaklanmaktadır. Dolayısıyla yerel seçimler özelinde düşünüldüğünde kimi zaman hemşericilik kimi zamanda hizmet odaklı yaklaşımların sergilendiği bu seçimlerde göze çarpmaktadır (Toprak, 2011, s. 314). Dolayısıyla yerel yönetimlerde aday için çizilen ve seçmenlere sunulan imajın bir parçası konumundaki başarı profili adayların politik kimliklerinin önüne geçebilmektedir. 


\section{Adayın İletişim Becerileri}

Seçime katılan adayların iletişim becerilerindeki mahareti onların seçmenle kuracakları bağ açısından önemlidir. Ayrıca sosyalleşme düzeyi yüksek olan adayların iletişim becerilerinin de yüksek olması beklenmektedir. Fiziksel ve ideolojik olarak düşünüldüğünde adayların imajları, sosyal yaşantıdaki tutumları, işe yaklaşım şekilleri, iş yaşantısında çalışanlarla olan iletişimi, yerel seçimi kazanması durumunda görevinde kendisinden beklenen tutum ve davranışlar, konulara yaklaşım biçimi, grup karşısındaki hitabet yeteneği gibi konularla doğrudan ilintilidir. Dolayısıyla politik imajlar sadece kişisel özelliklerden ibaret değil, adayın seçmen üzerinde bıraktığı etkinin tamamından oluşmaktadır. Adayların imajları seçmenler üzerinde hem lider olarak hem de kişi olarak değerlendirilmekte, bilişsel düzeyde onları etkilemektedir (Hacker, Walter R. Zakahi, \& McQuitty, 2000, s. 235). Bu nedenle de seçmenleriyle ya da diğer bir ifadeyle hedef kitlesiyle etkin ve başarılı iletişim/etkileşim içinde olan adayların pozitif ilişkiler geliştirmesi, imajlarının seçmenlerin belleklerinde daha olumlu şekilde gelişmesini sağlarken, adayları rakipleri karşısında üstün kılabilmektedir.

\section{Siyasi Konjonktür ve Çevresel Eğilim}

Konjonktür Türk Dil Kurumu tarafından "geçerli durum ya da her türlü durum ve şartın ortaya çıkardığı sonuç" ş̧eklinde tanımlanmaktadır. Siyasi şartların, birey üzerinde meydana getirdiği etki çevresel eğilim ile şekillenir ve aday imajının oluşumunda etkilidir. Özellikle aile hatta bireyin yakın çevresi henüz küçük yaşlardan itibaren kişiyi siyasal yaşantıyla ilgili bilgilendirmekte, onun belleğine siyasal yaşamla ilgili fikirlerin yerleşmesine aracı olmaktadır. Dolayısıyla aile ve yakın çevre bireylerin siyasallaşmasında önemli bir etkendir. Zira apolitik bir aileye ya da yakın çevreye sahip bireylerin de siyasallaşmaya düzeyleri farklıdır (Tokgöz, 2010, s. 109). Bu bağlamda ailelerinin ya da yakın çevrelerinin destekledikleri bir siyasal partiye olan bağlarının temelinin bireyde küçük yaşlardan itibaren oluştuğu düşünülmekte, bu kapsamda geliştirilen partiyle özdeşleşme modeli önem arz etmektedir. Zira partiyle özdeşleşme modeline göre bireyler siyasal yaşantıya yönelmeden önce siyasetle ilgilenmekte ve sosyal çevresinin etkisiyle hem siyasal görüşlerini şekillendirmekte hem de sosyal çevresinin aynası gibi yansıtmaktadır (Kalender, 2000, s. 47). Zaman içinde sürekli bu etkiye maruz kalan bireylerin kendilerini bir partiyle ya da siyasal görüşle özdeşleștirmeleri de doğal bir sonuçtur. Zira sosyal çevreleri tarafından sürekli övgüyle bahsedilen adaylara karşı seçmenlerin yönelmesi çok da olağan bir durumdur. Ayrıca kendisinden sürekli bahsedilen adayın ülkede süren olumlu atmosfer ve hakim siyasal konjonktürle de olan yakınlığı ya da uzaklığı seçmenin ilgilendiği bir diğer konudur. Ülkenin durumundan ya da siyasal konjonktürden memnun olan bir seçmenin benzer görüşteki bir adaya karşı olumlu bakması da normaldir.

\section{Medya}

Kitle iletişim araçlarının seçmenler üzerindeki etkisi bilinmektedir. Medya olarak da tanımlanan kitle iletişim araçları vasıtasıyla adaylar daha büyük seçmen kitlelerine ulaşabilmekte, mesajlarını daha etkin bir şekilde iletebilmektedir. Dolayısıyla medyanın kitlesel olarak bireylere istenilen mesajları iletebilme kapasitesi adaylar tarafından yakından takip edilmekte, seçim kampanyalarında medyaya ayrı bir özen gösterilmektedir. Özellikle seçim atmosferlerinde ise adaylar bütün medya ortamlarını etkili olarak kullanmayı seçmenler üzerinde iyi izlenim bırakmayı hedeflemektedirler. Günümüz dünyasında siyasetin medya aracılığıyla şekillendiği unutulmamalıdır. Dolayısıyla sembolik ve törensel olarak imajlar çerçevesinde işleyen siyasetin 
olabildiğince kişiselleştirilmiş boyutu, kimi zaman dramatize edilmiş, kimi zaman ise basite indirgenmiş, eğlence yönü ön plana çıkartılmaya çalışılmıştır (Çebi, 2002 Akt. Damlapınar Balcı, 2014, s. 133). Hal böyleyken siyasetçiler için oluşturan imajlar medya ile kimi zaman şekillendirilmektedir. Diğer bir deyişle medya adayların/liderlerin imajlarının gösterildiği, şekillendiği, rötuşlandığı ya da ön plana çıkarılması istenen kısımların parlatıldığı bir alandır. Bu nedenledir ki; adaylar medyayla olan ilişkilerine, medyadaki sunumlarına, medyaya karşı tavırlarına ayrı bir hassasiyet göstermelidir.

\section{Araştırmanın Metodolojisi}

Modern demokratik toplumlarda iktidarların belirleyicisi olan seçmenlerin tercihlerini belirlemede aday imajının ne derece etkili olduğunu anlamaya yönelik olarak yapılan bu çalışmanın, veri toplama işlemi Sivas İli merkezinde 5 Nisan - 30 Nisan 2019 tarihleri arasında yapılmıştır. 31 Mart 2019 yerel seçimlerinde Sivas ili merkez sınırları içerisinde oy verme hakkına sahip bireyler çalıșmanın ana kütlesi olarak belirlenmiştir. Çalışmadaki örneklem seçimi ise basit tesadüfi örnekleme yöntemi ile gerçekleştirilmiştir. Bu bağlamda Sivas ili Merkez sınırları içinde rastgele seçilen ve araştırmaya katılmak isteyen bireylerle yüz yüze görüşülerek 537 anket uygulanmıștır. Anket uygulamasında Sivas Cumhuriyet Üniversitesi İletişim Fakültesi öğrencilerinden anketör olarak destek alınmıştır. Anket uygulamasında katılımcıları etkileyebilecek, onları yönlendirebilecek konuşmalardan, tutumlardan ve davranışlardan bilhassa uzak durulmaya çalıșılarak katılımcıların ankete içtenlikle cevap vermeleri istenmiştir.

Araştırmada kullanılan anket formunun ilk bölümünde seçmenlerin kararları üzerinde aday imajının ne derece etkili olduğunun anlaşılması adına beşli likert ölçeği ile hazırlanmış 20 soru katılımcılara yöneltilmiștir. Anketin ikinci bölümünde ise çalıșmaya katılanların siyasal tutum ve davranışlarının belirlenmesine yönelik olarak soru hazırlanmıştır. Anketin üçüncü bölümü çalışmaya katılanların siyasal konulardaki bilgi edinme yöntemlerini anlamak için hazırlanan sorulardan oluşmaktadır. Dördüncü bölümde ise katılımcıların gelir, cinsiyet, yaş, meslek vb. demografik özelliklerinin belirlenmesi için sorular hazırlanmıştır. Çalışmada Balcı ve Damlapınar'ın Siyasal iletişimde Seçimler, Adaylar ve İmajlar (2014) isimli çalışmalarında için geliştirdikleri 2009 Yerel Seçimlerde Aday İmajının Oluşumda Etkili Faktörler isimli anket formu ve ölçek kullanılmıştır.

Ayrıca 2019 Yerel Seçimlerinde aday imajının seçmen tercihleri üzerindeki etkisi araştırılırken kullanılan demografik değişkenlerin aday imajına yönelik faktörlere göre anlamlılık düzeyleri de araştırılmıștır.

\section{Araştırma Soruları}

Sivas ilinde 31 Mart 2019 Yerel Seçimlerine oy kullanarak çalışmaya katılan seçmenlerin oy tercihlerinin belirlenmesinde etkili faktörler ve aday imajının bu süreçteki etkisini belirlemek amacıyla gerçekleştirilen araştırmada şu sorulara cevaplar aramıştır.

\section{Araştırma Sorusu 1:}

Seçmenlerin meslekleriyle oy kullanım tercihleri arasında nasıl bir ilişki vardır?

\section{Araştırma Sorusu 2:}

2019 Yerel Seçimlerinde oy kullanan seçmenler oy tercihlerini ne zaman belirlemektedir?

\section{Araştırma Sorusu 3:}

Araştırmaya katılan bireylerin oy tercihlerini etkileyen faktörler arasında nasıl bir ilişki bulunmaktadır? 


\section{Araştırma Sorusu 4:}

2019 Yerel Seçimlerinde oy kullanan seçmenlerin oy kararlarını etkileyen faktörler nelerdir?

Araştırma Sorusu 5:

2019 Yerel Seçimlerinde oy kullanan seçmenlerin en son yerel seçimlerde adaya oy verirken dikkat ettiği özellikler nelerdir?

Araştırma Sorusu 6:

2019 Yerel Seçimlerinde oy kullanan seçmenlerin oy verdikleriyle siyasi partiye olan bağlılık düzeyleri ne șekildedir?

Araştırma Sorusu 7:

Araştırmada kullanılan faktör gruplarının cinsiyetlere göre farklılıkları bulunmakta midir?

\section{Etik Kurul İzni}

Sivas Cumhuriyet Üniversitesi Bilimsel Araștırma ve Yayın Etiği Sosyal ve Beșeri Bilimler Kurulu 28/09/2020 tarih ve 12 no'lu toplantısında alınan karar çerçevesinde çalışma etik açıdan bir sakınca içermemektedir.

\section{Araştırmanın Bulguları ve Yorumlar}

$\mathrm{Bu}$ başlık altında araştırmaya katılım gösteren bireylerin yerel seçimlerde oy verme tercihleri üzerinde aday imajının etkisi ölçülmeye çalıșılmıştır. Ayrıca yerel seçimlerde seçmenlerin kararları üzerinde etkili olduğu düşünülen araçların belirlenmesi ve katılımcıların demografik özellikleriyle ilgili genel bilgilere yer verilmiştir.

\section{Katılımcıların Demografik Özelliklerine İlişkin Genel Bilgiler}

Katılımcıların demografik özelliklerine ilişkin genel bilgiler aşağıda bulunan Tablo 1'de ele alınmıştır. 
Tablo 1. Araştırmaya Katılanları Yönelik Tanımlayıcı Bilgilere Ait Frekans ve Yüzdeler

\begin{tabular}{|c|c|c|c|c|c|}
\hline Cinsiyet & Frekans & Yüzde & Meslek & Frekans & Yüzde \\
\hline Erkek & 326 & 60,7 & İşçi & 43 & 8,0 \\
\hline Kadın & 211 & 39,3 & Memur & 43 & 8,0 \\
\hline Toplam & 537 & 100 & Esnaf & 55 & 10,2 \\
\hline Eğitim Durumu & Frekans & Yüzde & Serbest Meslek & 54 & 10,1 \\
\hline Okuryazar Değilim & 8 & 1,5 & Emekli & 25 & 4,7 \\
\hline Okuryazarım & 12 & 2,2 & Sanayici/Tüccar & 7 & 1,3 \\
\hline İlkokul Mezunuyum & 36 & 6,7 & Ev Hanımı & 30 & 5,6 \\
\hline Ortaokul Mezunuyum & 29 & 5,4 & Öğrenci & 245 & 45,6 \\
\hline Lise Mezunuyum & 105 & 19,6 & Diğer & 35 & 6,5 \\
\hline $\begin{array}{c}\text { Üniversite Mezunuyum/ } \\
\text { Okuyorum }\end{array}$ & 308 & 57,4 & Total & 537 & 100,0 \\
\hline $\begin{array}{c}\text { Lisansüstü Mezunuyum/ } \\
\text { Okuyorum }\end{array}$ & 39 & 7,3 & Gelir Düzeyi & Frekans & Yüzde \\
\hline Total & 537 & 100,0 & 2200 TL ve altı & 162 & 30,2 \\
\hline Yaş & Frekans & Yüzde & $2201 \mathrm{TL}-3800 \mathrm{TL}$ & 179 & 33,3 \\
\hline 18-23 Yaş & 225 & 41,9 & $3801 \mathrm{TL}-5400 \mathrm{TL}$ & 127 & 23,6 \\
\hline 24-29 Yaş & 122 & 22,7 & $5401 \mathrm{TL}-7000 \mathrm{TL}$ & 33 & 6,1 \\
\hline 30-35 Yaş & 51 & 9,5 & 7001 TL ve üstü & 36 & 6,7 \\
\hline 36-41 Yaş & 47 & 8,8 & Total & 537 & 100,0 \\
\hline 42 ve üstü Yaş & 92 & 17,1 & & & \\
\hline Total & 537 & 100 & & & \\
\hline
\end{tabular}

Araştırmada yer alan 537 katılımcıya ait demografik bilgilere Tablo 1'de ayrıntılı olarak yer verilmiştir. Tablo 1'de yer alan verilere göre katılımcıların \%60,7'si erkeklerden, \%39,3'ü kadınlardan oluşmaktadır. Katılımcıların eğitim durumları incelendiğinde \%1,5'i okuryazar olmayan, \%2,2'si okuryazar, \%6,7'si ilkokul mezunu, \%5,4'ü ortaokul mezunu, \%19,6'sı lise mezunu, \%57,4'ü üniversite mezunu/öğrencisi, \%7,3'ü lisansüstü mezunu/öğrencisidir. Katılımcıların yaşlarına ilişkin soruya verdikleri cevaplar neticesinde ise; katılımcıların \%41,9'unun 18-23 yaş aralığında, \%22,7'sinin 24-29 yaş aralığında, \%9,5'unun 30-35 yaş aralığında, \%8,8'inin 36-41 yaş aralığında, \%17,1'inin 42 ve üstü yaş yaş aralığında olduğu anlaşılmaktadır. Katılımcıların mesleklerine ilişkin sorulara verdikleri cevaplar incelendiğinde ise \%8'inin işçi, \%8'inin memur, \%10,2'sinin esnaf, \%10,1'inin serbest meslek, \%4,7'inin emekli, \%1,3'ünün sanayici/tüccar, \%5,6'sının ev hanımı, \%45,6'sının öğrenci, \%6,5'inin diğer meslek gruplarına ait olduğu sonucuna ulașılmıștır. Katılımcıların gelir düzeylerine ilişkin soruya verdikleri cevaplar incelendiğinde \%30,2'sinin 2.200 TL ve altı, \%33,3'ünün 2.201-3.800 TL, \%6,1'inin 5.401-7.000 TL, 6,7'sinin 7.001 TL ve üstü gelir düzeyine sahip oldukları görülmektedir.

\section{Katılımcıların Siyasal Tercihlerine İlişkin Genel Bilgiler}

Bu başlıkta araştırmaya katılan bireylerin anketlere verdikleri cevaplar üzerinden siyasal tercihlerine ilişkin elde edilen genel bilgiler değerlendirilmiştir. 
Tablo 2. Araștırmaya Katılanların Bir Önceki Yerel Seçimde Hangi Partiye Oy Verdikleri

\begin{tabular}{|l|c|c|}
\hline PARTi isiMLERI & Frekans & Yüzde \\
\hline AK Parti & 218 & 40,6 \\
\hline CHP & 110 & 20,5 \\
\hline MHP & 110 & 20,5 \\
\hline SP & 9 & 1,7 \\
\hline Diğer & 90 & 16,8 \\
\hline Total & 537 & 100,0 \\
\hline
\end{tabular}

Araştırmaya katılanlara, hangi siyasi partiye oy verdikleri sorulduğunda; katılımcıların \%40,6'sı AK Parti'ye oy verdiklerini belirtmişlerdir. Sivas ilinde yaplan yerel seçimlerde AK Partinin yaklaşık \%49 oy alarak kazandığı düşünüldüguünde yaklaşık bir sonuç elde edilmiştir. Araştırmaya katılanların en çok oy verdiklerini beyan ettikleri parti ise ikinci olarak \%20,5'lik oylara sahip olan CHP ile MHP'dir. Ayrıca araştırmaya katılanların \%1,7'si SP'ne ve \%16,8'i ise diğer partilere oy verdiklerini beyan etmiştir. 
Tablo 3. Araştırmaya Katılanların Oy Verme Davranışı Üzerinde Etkili Olan Araçlar

\begin{tabular}{|c|c|c|c|c|c|c|c|}
\hline \multirow{7}{*}{ 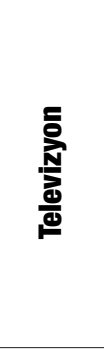 } & Etki Düzeyi & Frekans & Yüzde & \multirow{7}{*}{ 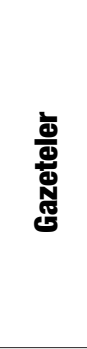 } & Etki Düzeyi & Frekans & Yüzde \\
\hline & Hiçbir Etkisi Olmadı & 103 & 19,2 & & Hiçbir Etkisi Olmadı & 152 & 28,3 \\
\hline & Etkili Olmadı & 70 & 13,0 & & Etkili Olmadı & 125 & 23,3 \\
\hline & Biraz Etkili Oldu & 121 & 22,5 & & Biraz Etkili Oldu & 121 & 22,5 \\
\hline & Etkili Oldu & 105 & 19,6 & & Etkili Oldu & 75 & 14,0 \\
\hline & Çok Etkili Oldu & 138 & 25,7 & & Çok Etkili Oldu & 64 & 11,9 \\
\hline & Toplam & 537 & 100 & & Toplam & 537 & 100 \\
\hline \multirow{7}{*}{ 윯 } & Etki Düzeyi & Frekans & Yüzde & \multirow{7}{*}{ 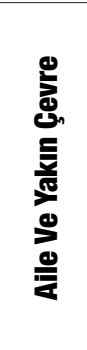 } & Etki Düzeyi & Frekans & Yüzde \\
\hline & Hiçbir Etkisi Olmadı & 232 & 43,2 & & Hiçbir Etkisi Olmadı & 115 & 21,4 \\
\hline & Etkili Olmadı & 134 & 25,0 & & Etkili Olmadı & 97 & 18,1 \\
\hline & Biraz Etkili Oldu & 81 & 15,1 & & Biraz Etkili Oldu & 138 & 25,7 \\
\hline & Etkili Oldu & 55 & 10,2 & & Etkili Oldu & 105 & 19,6 \\
\hline & Çok Etkili Oldu & 35 & 6,5 & & Çok Etkili Oldu & 82 & 15,3 \\
\hline & Toplam & 537 & 100 & & Toplam & 537 & 100 \\
\hline \multirow{7}{*}{ 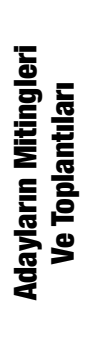 } & Etki Düzeyi & Frekans & Yüzde & \multirow{7}{*}{ 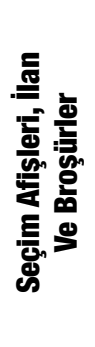 } & Etki Düzeyi & Frekans & Yüzde \\
\hline & Hiçbir Etkisi Olmadı & 100 & 18,6 & & Hiçbir Etkisi Olmadı & 167 & 31,1 \\
\hline & Etkili Olmadı & 70 & 13,0 & & Etkili Olmadı & 93 & 17,3 \\
\hline & Biraz Etkili Oldu & 135 & 25,1 & & Biraz Etkili Oldu & 124 & 23,1 \\
\hline & Etkili Oldu & 130 & 24,2 & & Etkili Oldu & 89 & 16,6 \\
\hline & Çok Etkili Oldu & 102 & 19,0 & & Çok Etkili Oldu & 64 & 11,9 \\
\hline & Toplam & 537 & 100,0 & & Toplam & 537 & 100,0 \\
\hline \multirow{7}{*}{ 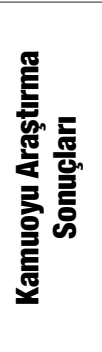 } & Etki Düzeyi & Frekans & Yüzde & \multirow{7}{*}{$\begin{array}{l}\text { 흘 } \\
\text { 를 }\end{array}$} & Etki Düzeyi & Frekans & Yüzde \\
\hline & Hiçbir Etkisi Olmadı & 136 & 25,3 & & Hiçbir Etkisi Olmadı & 75 & 14,0 \\
\hline & Etkili Olmadı & 94 & 17,5 & & Etkili Olmadı & 59 & 11,0 \\
\hline & Biraz Etkili Oldu & 120 & 22,3 & & Biraz Etkili Oldu & 121 & 22,5 \\
\hline & Etkili Oldu & 102 & 19,0 & & Etkili Oldu & 123 & 22,9 \\
\hline & Çok Etkili Oldu & 85 & 15,8 & & Çok Etkili Oldu & 159 & 29,6 \\
\hline & Toplam & 537 & 100,0 & & Toplam & 537 & 100,0 \\
\hline \multirow{7}{*}{ 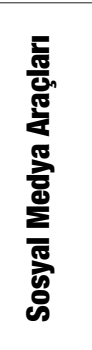 } & Etki Düzeyi & Frekans & Yüzde & & & & \\
\hline & Hiçbir Etkisi Olmadı & 95 & 17,7 & & & & \\
\hline & Etkili Olmadı & 57 & 10,6 & & & & \\
\hline & Biraz Etkili Oldu & 122 & 22,7 & & & & \\
\hline & Etkili Oldu & 91 & 16,9 & & & & \\
\hline & Çok Etkili Oldu & 172 & 32,0 & & & & \\
\hline & Toplam & 537 & 100,0 & & & & \\
\hline
\end{tabular}

Katılımcıların oy verme davranışları üzerinde nelerin etkili olduğunun anlașılması amaciyla anket formunda yer verilen soruya ait cevaplara ait verilere, Tablo 3'te yer verilmiştir. Buna göre katılımcıların \%19,2'si televizyonun oy verme kararları üzerinde hiçbir etkisi olmadığını savunmuşlardır. Aynı soruya diğer katılımcıların ise \%13'ü etkili olmadı, \%22,5'i biraz etkili oldu, \%19,6'sı etkili oldu, \%25,7'si çok etkili oldu cevabını vermişlerdir. Daha önceki yapılan çalışmalarda incelendiğinde televizyonun seçmenler üzerindeki etkisi olduğu saptanmıştır. Elde edilen bu sonuç ile Baltacı ve Eke'nin 2012 yılında "Siyasal Propaganda Araçlarının Seçmen Davranışı Üzerindeki Etkisine Yönelik Seçmen Algısı: Isparta Örnek Olayı" isimli çalışmasında televizyonun seçmen üzerindeki etkisine yönelik elde ettikleri sonuçlarla benzerlik göstermektedir (2012, s. 123). 
Yine aynı soruda gazetelerin katılımcıların oy kararları üzerindeki etkisi ölçülmek istenmiştir. $\mathrm{Bu}$ amaçla sorulan soruya katılımcıların \%28,3'i gazetelerin oy verme davranışları üzerinde hiçbir etkisi olmadığını savunurken, \%23,3'ü etkili olmadı, \%22,5'i biraz etkili oldu, \%14'ü etkili oldu, \%11,9'u çok etkili oldu şeklinde cevap vermiştir.

Radyonun oy verme davranışı üzerindeki etkisine ilişkin yönetilen soruya ise katılımcıların \%43,2'si hiçbir etkisi olmadı cevabını vermiştir. Radyonun seçmen tercihleri üzerindeki etkisinin hiç ya da çok az olduğunu savunan katılımcı oranı yaklaşık \%68'dir. Radyonun çok ya da belirli bir oranda etkisinin olduğunu savunanlar ise yaklaşık \%31'lik bir orana tekabül etmektedir. Dolayısıyla radyo seçmen tercihleri üzerinde kısıtlı bir etkiye sahip kitle iletişim aracıdır. Doğan ve Göker (2010, s. 176) tarafından Elazı '̆'da yapılan çalışmada radyo haberleri ve konuşmalarının seçmenler üzerinde etkili olduğu saptanırken yapılan bu çalışmada radyonun etkisinin kısıtlı olduğu belirlenmiştir. Dolayısıyla başta internet olmak üzere gelișen teknolojiyle birlikte radyo, seçimlerdeki etkinliğini kaybetmiştir.

Katılımcıların aile ve yakın çevrelerinin oy verme davranışları üzerindeki etkisinin belirlenmesi amacıyla sorulan soruya ise; katılımcıların \% 21,4'inin hiçbir etkisi olmadı, \%18,1'inin etkili olmadı, \%25,7'sinin biraz etkili oldu, \%19,6'sının etkili oldu, \%15,3'ünün çok etkili oldu şeklinde cevap verdiği saptanmıştır. Ailenin ve yakın çevrenin seçmen tercihleri üzerindeki etkili olduğu bilinmektedir. Bu etki genellikle de azımsanmayacak bir düzeydedir. Örneğin Aydın ve Özbek (2004, s. 165) tarafından yapılan "Ailenin Seçmen Davranışları Üzerine Etkisi” isimli çalışmada aile kurumunun bireyin siyasal tercihinde önemli bir rol oynadığı belirlenmiştir. Yapılan bu çalışmada katılımcılar üzerinde ailenin etkisinin yaklaşık olarak yüzde ellinin üzerinde olduğu saptanmıştır.

Seçim kampanyalarının önemli faaliyetlerinden biri olan adaylar tarafından yapılan toplantı ve mitinglerin seçmen tercihleri üzerinde etkili olduğu düşünülmektedir. $\mathrm{Bu}$ amaçla katılımcılara yöneltilen soruya katılımcıların \%18,6'sı hiçbir etkisi olmadı, \%13'ü etkili olmadı, \%25,1'i biraz etkili oldu, \%24,2'si etkili oldu, \%19'u çok etkili oldu şeklinde cevap vermiştir.

Katılımcıların \%31,1'i seçim afişleri, ilan ve broşürlerin oy verme kararları üzerinde hiçbir etkisi olmadığını savunurken, yine aynı soruya katılımcıların \%17,3'ünün seçim afişleri, ilan ve broşürlerin kendi kararları üzerinde etkili olmadığını, \%23,1'i biraz etkili olduğunu, \%16,6'sı etkili olduğunu, \%11,9'u çok etkili olduğunu belirtmiştir.

Kamuoyu araştırma sonuçlarının ise seçmen davranışları üzerindeki etkisi incelendiğinde katılımcıların \%25,3'ü üzerinde hiçbir etkisi olmadığı, \%17,5'si üzerinde etkili olduğu, \%22,3'ü üzerinde biraz etkili olduğu, \%19'u üzerinde etkili olduğu, \%15,8'i üzerinde ise çok etkili olduğu saptanmıştır.

İnternetin katılımcıların oy verme davranışları üzerindeki etkisine yönelik soruya cevapların \%14'ü tarafından hiçbir etkisi olmadı, \%11'i tarafından etkili olmadı, \%22,5'i tarafından biraz etkili oldu, \% 22,9'u tarafından etkili oldu, \%29,6'sı çok etkili oldu şeklinde olmuştur. Seçmen tercihlerinde internetin ne derece etkili olduğu sürekli tartışılan bir konudur. Son dönem yapılan araştırmalarda bu konuya eğilmekte, seçim kampanyaları internet üzerinden sürekli desteklenmekte ve güncellenmektedir. Adaylara internet siteleri kurulmakta, siyasal partiler özellikle seçim zamanları daha aktif ziyaret edilen internet sitelerini güncel tutmaktadır. Damlapınar ve Balcı (2014, s. 205) tarafından daha önce yapılan çalışmada internetin seçmen kararları üzerindeki etkisinin 
yaklaşık \%40’lık bir oranda olduğu saptanmıştır. 2019 Yerel Seçimleri üzerine yapılan bu çalışmada da internetin etkisi ise yaklaşık \%70’lerde çıkmıştır. Dolayısıyla geçen zaman içerisinde seçmenlerin tercihleri üzerinde internetin etkisi artmıştır.

Oy verme davranışları üzerinde en etkili araçlardan biri olan sosyal medya araçları için katılımcılar \% 17,7 hiçbir etkisi olmadı, \% 10,6 etkili olmadı, \% 22,7 biraz etkili oldu, \% 16,9 etkili oldu derken, \% 32,0 oranla çok etkili oldu cevabını vermişlerdir. Elde edilen bu sonuç seçmen kararlarında ve siyasal davranışlarında sosyal medyanın etkisi olduğunu belirten Dursunoğlu'nun (2017, s. 1584) çalışmasını destekler niteliktedir. Çünkü Dursunoğlu çalışmasının sonuç kısmında sosyal medyanın seçmenler üzerindeki etkisinin net bir şekilde olduğunu ifade etmektedir. 2019 Yerel Seçimleri özelinde yapılan bu çalışmada da sosyal medyanın seçmenler üzerinde net bir etkisi olduğu saptanmıştır.

\section{Katılımcıların Oy Tercihleri ve Adayların Özelliklerine İlişkin Değerlendirmeleri}

Araştırmaya katılan 537 seçmenin oy tercihlerini belirlerken, adaylarla, siyasal partilerle, seçim kampanyalarıyla vd. dikkat ettikleri özelliklere ilişkin değerlendirmelerine ilişkin sorulara verdikleri yanıtların cevapları bu başlıkta değerlendirilmiştir..

Tablo 4. Katılımcıların En Son Yerel Seçimlerde Adaya Oy Verirken Dikkat Ettiği Özellikler

\begin{tabular}{|l|c|c|}
\hline Katılımcıların En Son Yerel Seçimlerde Adaya Oy Verirken Dikkat Ettiği Özellikler & Frekans & Yüzde \\
\hline Adayın Kendisi & 150 & 27,9 \\
\hline Adayın Partisi & 109 & 20,3 \\
\hline Medya & 45 & 8,4 \\
\hline Adayın Seçim Kazanma İhtimali & 20 & 3,7 \\
\hline Adayın ve Partinin Katılımcıyla İetişimi & 17 & 3,2 \\
\hline Seçim Döneminde Ülkedeki Mevcut Durum ve Konjonktür & 67 & 12,5 \\
\hline Adayın Dini ve Ahlaki Değerleri & 34 & 6,3 \\
\hline Adayın İdeolojisi & 75 & 14,0 \\
\hline Diğer & 20 & 3,7 \\
\hline Total & 537 & 100,0 \\
\hline
\end{tabular}

En son yerel seçimlerde adaya oy verirken katılımcıların adayla ilgili dikkat ettikleri özelliklerin onların kararları üzerindeki etkisini belirlemek amacıyla anket formunda bir soruya yer verilmiștir. Anket formunda yer verilen bu soruya katılımcıların \%27,9'u "adayın kendisi" şeklinde cevap verirken \%20,3'ü "adayın partisi”, \%8,4'ü "medya", \%3,7'si "adayın seçimi kazanma ihtimali", \%3,2'si "adayın ve partinin katılımcıyla iletişimi”, \%12,5'i "seçim döneminde ülkedeki mevcut durum ve konjonktür", \%6,3'ü "adayın dini ve ahlaki değerleri", \%14'ü "adayın ideolojisi", \%3,7'si ise "diğer" şeklinde yanıtlamıştır. Elde edilen sonuçlar bazında düşünüldüğünde özellikle yerel seçimlerde seçmenler adayların "kim olduğu" ve "hangi partiden" aday olduğuna daha dikkat etmektedir. Dolayısıyla yerel seçimlerde partiyle özdeşleşme modelinin geçerli olduğu sonucu Tablo 4'teki veriler ıșığında ortaya çıkmıștır. Bilindiği üzere partiyle özdeşleşme modeli seçmenlerin herhangi bir partiye duydukları aidiyet ya da bağlılık düzeyleriyle ilgilidir (Kalender, 2000, s. 48). 2019 Yerel Seçimlerinde seçimlere katılan adayların kim olduğu sorusu seçmen tercihlerini doğrudan etkilemektedir. 
Tablo 5. Seçmenin Gözünde Belediye Başkanları İçin En Uygun Meslek

\begin{tabular}{|l|c|c|}
\hline Seçmenin Gözünde Belediye Başkanları İçin En Uygun Meslek & Frekans & Yüzde \\
\hline Mimar veya Mühendis & 114 & 21,2 \\
\hline Hukukçu & 62 & 11,5 \\
\hline Eğitimci & 92 & 17,1 \\
\hline Bürokrat & 55 & 10,2 \\
\hline İşadamı & 44 & 8,2 \\
\hline Meslek Önemli Değil & 140 & 26,1 \\
\hline Diğer & 30 & 5,6 \\
\hline Total & 537 & 100,0 \\
\hline
\end{tabular}

Katılımcılara belediye başkanları için en uygun mesleğin ne olduğunun anlașılmasına yönelik bir soru yönetilmiş ve bu soruya verdikleri cevaplar Tablo 5'te sunulmuştur. Bu tablodaki verilere göre katılımcılardan \%21,2'i belediye başkan adaylarının mimar veya mühendis, \%11,5'i hukukçu, \%17,1'i eğitimci, \%10,2'si bürokrat, \%8,2'si işadamı, \%26,1'i adayın mesleğinin önemli olmadığını ve \%5,6'sı ise bu soruda yer verilen mesleklerin dışında bir mesleğe sahip olması gerektiğini ifade etmiştir. Araştırmaya katılan seçmenlerin bir kısmının adayın mesleğiyle pek ilgilenmediklerini belirtmelerine rağmen mimar ve mühendis olmasını isteyen bir grup seçmende bulunmaktadır. Seçmenlerin özellikle mimar ve mühendislerin şehirleşmenin doğru bir şekilde yapılmasına katkı sağlayacakları yönündeki inançları neticesine bağlı olarak bu sonucun ortaya çıkmış olacağ düşünülmektedir.

Tablo 6. Seçmenin Seçimden Önce Adayla Yaptığı Görüşme

\begin{tabular}{|l|c|c|}
\hline Seçimden Önce Adayla Yapılan Görüşme & Frekans & Yüzde \\
\hline Hiç Görüşmedim & 381 & 70,9 \\
\hline Bir veya Birkaç Kez Görüştüm & 121 & 22,5 \\
\hline Sık Sık Görüşme Fırsatım Oldu & 35 & 6,5 \\
\hline Total & 537 & 100,0 \\
\hline
\end{tabular}

Özellikle yerel seçimler adayların seçmenler ile doğrudan temas kurabildikleri seçimler olarak öne çıkmaktadır. Katılımcıların seçmenler ile iletişim kurup kurmadıklarını belirlemek amacıyla da anket formunda bir soruya verilmiștir. Katılımcıların bu soruya verdikleri cevaplara ilişkin veriler Tablo 6'da sunulmuştur. Katılımcıların \%70,9'u seçimden önce adayla hiç görüșme yapmamıştır. \%22,5'si ise bir veya birkaç kez görüşmüş, \%6,5'i sık sık görüşme firsatı bulmuştur. Nitekim seçmenlerin büyük çoğunluğu adayla seçimden önce doğrudan bir iletişim kurmamış, oy vereceği partiyi daha önceki tablolardan da anlaşılabileceği gibi kendi yakın çevresinin görüşüne, internet ve sosyal medyadaki bilgilere ya da adayın partisine göre öncelikli olarak belirlemiștir.

Tablo 7. Yerel Seçimlerde Seçmenin Karar Verme Süreci

\begin{tabular}{|l|c|c|}
\hline Son Yerel Seçimlerde Seçmenin Karar Verme Süreci & Frekans & Yüzde \\
\hline Seçim Dönemi Olmasa Bile Hangi Partiye Oy Vereceğim Zaten Bellidir & 203 & 37,8 \\
\hline Seçim Kararı Alınıp Adaylar Belirlendiğinde & 209 & 38,9 \\
\hline Seçim Kampanyasının Ortasında & 53 & 9,9 \\
\hline Oylamaya Bir Kaç Gün Kala & 34 & 6,3 \\
\hline Sandık Başında & 38 & 7,1 \\
\hline Total & 537 & 100,0 \\
\hline
\end{tabular}

2019 Yerel seçimlerinde araştırmaya katılan seçmenlerin oy verecekleri parti ya da adaya ilişkin kararlarını ne zaman belirlediklerini saptamaya yönelik anket formuna bir soru 
konulmuş olup, katılımcıların bu soruya verdikleri yanıtlara ilişkin veriler Tablo 7'de yer almaktadır. Elde edilen verilere göre katılımcıların \%37,8'i soruya "seçim dönemi olmasa bile hangi partiye oy vereceğim zaten bellidir" şeklinde cevap vermiştir. Seçim kararı alınıp adaylar belirlendiğinde oy kararı belirleyenler ise \%38,9 ile en yüksek orana sahiptir. Ayrıca araştırmaya katılanların \%9,9'u "seçim kampanyası ortasında", \%6,3'ü "oylamaya birkaç gün kala”, \%7,1 "sandık başında” kararlarını belirlediklerini ifade etmiştir. Tablo 7'deki sonuçlara bakıldığında seçmenlerin yaklaşı \% 40 ’ının seçim dönemi olmasa bile kararlarının her daim belli olduğu, dolayısıyla partiyle özdeşleşme modelinin yerel seçimler için doğru bir yaklaşım olarak algılanması gerekliliği doğmaktadır. Yerel seçimlerde doğru adayı belirleyen ve belirli seçmen potansiyeline sahip partilerin başarılı olma ihtimali Tablo 7'deki verilere göre olabilirliği yüksek bir sonuç olarak algılanmaktadır. Ayrıca ortaya çıkan bu veriler Damlapınar ve Balcı (2014, s. 169) tarafından Ankara seçmenleri üzerinde yapılan araştırmanın sonuçlarıyla paralellik göstermektedir.

Tablo 8. Seçmenlerin Siyasal Konulara İlgi Düzeylerini Tanımlayıcı İstatistikler

\begin{tabular}{|l|c|c|c|c|c|}
\hline Seçmenlerin İlgi Düzeyleri & Frekans & Minimum & Maksimum & Medyan & Std. Sapma \\
\hline $\begin{array}{l}\text { Son Yerel Seçimde Oy Verdiğiniz } \\
\text { Siyasi Partiye Bağlılık Dereceniz }\end{array}$ & 537 & 1,00 & 10,00 & 5,6257 & 2,74941 \\
\hline $\begin{array}{l}\text { Seçim Döneminde Siyasal } \\
\text { Kampanya ve Konulara İlgi Düzeyi }\end{array}$ & 537 & 1,00 & 10,00 & 5,5549 & 2,80146 \\
\hline Ülke Sorunlarıyla İlgi Düzeyi & 537 & 1,00 & 10,00 & 7,1117 & 2,47950 \\
\hline
\end{tabular}

Araştırmaya katılan seçmenlerin siyasal konulara ilgi düzeylerini belirlemek amacıyla anket formunda sorular bulunmaktadır. Bu sorularda katılımcıların siyasal konulara ilgi düzeylerini "1" en düşük, "10" en yüksek olacak șekilde derecelendirmeleri istenmiștir. Elde edilen sonuçlara Tablo 8'de yer verilmiştir. Yapılan inceleme sonucunda katılımcıların "Son Yerel Secimde Oy Verdiğiniz Siyasi Partiye Bağlılık Dereceniz" sorusuna verdikleri yanıtların ortalamasının $(\bar{X}=5,6257)$ olduğu belirlenmiştir. Elde edilen bu bilgiler ışığında katılımcıların son yerel seçimde oy verdikleri siyasi partiye bağlılık derecelerinin orta düzeyde olduğu saptanmıştır. Yine araştırmaya katılan seçmenlerin "Seçim Döneminde Siyasal Kampanya ve Konulara İlgi Düzeyi"ni belirlemek amacıyla bir soru sorulmuş olup, bu soruya katılımcıların verdikleri yanıtların ortalamasının $(\bar{x}=5,5549)$ olduğu sonucuna ulaşılmıştır. Elde edilen bu sonuç ile çalışmaya katılan seçmenlerin 2019 Yerel Seçim Döneminde siyasal kampanya ve konulara ilgi düzeylerinin orta düzeyde olduğu belirlenmiştir. Katılımcıların "Ülke Sorunlarıyla İlgi Düzeylerini" belirlemek amacıyla sorulan soruya ilişkin verilerde Tablo 8'de yer almaktadır. Araştırmaya katılan seçmenlerin ülke sorunlarına olan ilgi düzeyleri ortalaması $(\bar{X}=7,1117)$ olarak belirlenmiştir. Dolayısıyla katılımcıların ülke sorunlarıyla olan ilgileri yüksek düzeydedir.

\section{Aday İmajlarının Katılımcıların Tercihleri Üzerine Etkisi}

Araştırmada 2019 Yerel Seçimlerindeki Adayların imajlarının seçmenlerin tercihlerini nasıl etkilediğini anlamaya yönelik sorulan sorular ve bu sorulara ilişkin değerlendirmeler bu başlık altında sunulmuştur.

Tablo 9. Güvenirlilik Geçerlilik

\begin{tabular}{|l|l|}
\hline \multirow{2}{*}{ Güvenirlilik Geçerlilik } & Cronbach's Alpha \\
\cline { 2 - 2 } &, 925 \\
\hline
\end{tabular}

Araştırmada kullanılan ölçeğe yönelik olarak güvenirlik ve geçerlilik analizi yapılmıştır. Özellikle çalışmalarda sıklıkla ölçeklerin güvenirlik ve geçerlilikleri Cronbach's Alpha 
(a) sayısı ile belirlenmektedir. Bu analizde Cronbach's Alpha değeri 0 ile 1 arasında yer almakta ve 1 değerine ne kadar yakın ise araştırmada kullanılan ölçeğin güvenirlilik ve geçerliliği o derece yüksek olmaktadır. Bazı araştırmalarda 0,5'e kadar kabul edilen bu sayının genellikle 0,7 ve üzerinde bir değerde olması istenmektedir. 2019 Yerel Seçimlerinde Seçmen Kararlarını belirlemeye yönelik faktörlere ilişkin bu araștırmada kullanılan ölçeğin Cronbach' Alpha değeri ise 0.925 çıkmıştır. Bu sonuç özellikle sosyal bilimler için 0,5 ve 0,7 değerlerinin de kabul edildiği düşünüldügünde araştırmada kullanılan ölçeğin güvenilir ve geçerli olduğu sonucunu ortaya koymaktadır.

Tablo 10. Faktör Yükleri ve Güvenirlik Sayıları

\begin{tabular}{|c|c|c|c|c|}
\hline \multicolumn{5}{|l|}{ FAKTÖR ANALIZi } \\
\hline Faktörler & 1 & 2 & 3 & 4 \\
\hline ÇEVRESEL EĞiLiM & \multicolumn{4}{|c|}{ Cronbach's Alpha $=, 866$} \\
\hline Adayı, görüşüne önem verdiğim insanların desteklemesi & 844 & & & \\
\hline Adayı çevremde yer alan insanların destekliyor olması & 842 & & & \\
\hline Adayı ailemin de desteklemesi & ,705 & & & \\
\hline Adayın kamuoyu araştırmalarına göre önde olması & ,680 & & & \\
\hline Adaya daha önce oy vermiş olmam & ,652 & & & \\
\hline Adayın seçimi kazanma ihtimali & ,614 & & & \\
\hline ADAYIN KARAKTERISTIĞi VE PARTISi & \multicolumn{4}{|c|}{ Cronbach's Alpha $=, 853$} \\
\hline Adayın iş bitiricilik ve girişkenlik yeteneği & & 848 & & \\
\hline Adayın yolsuzlukları önleme gücü ve etkisi & & ,811 & & \\
\hline Adayın gündemdeki sorunlar hakkında bir proje üretiyor olması & & 809 & & \\
\hline Adayın şehrin sorunları hakkındaki bilgisi ve ilgisi & & ,749 & & \\
\hline Adayın dürüst bir kişiliğe sahip olması & & ,701 & & \\
\hline SIYASI KONJONKTÜR VE BAŞARI, & \multicolumn{4}{|c|}{ Cronbach's Alpha = ,852 } \\
\hline Hükümeti başarılı görmem & & & ,766 & \\
\hline Adayın hükümetle uyumlu olması gerektiği yönünde yapılan açıklama & & & ,762 & \\
\hline Adayın halen aday olduğu görevi icra ediyor olması & & & ,759 & \\
\hline Adayın hükümet ve bürokrasi çevresiyle iyi ilişkilerde bulunması & & & ,736 & \\
\hline Adayın mensubu olduğu partinin iktidarda olması & & & ,705 & \\
\hline MEDYA VE İLETIŞiM & \multicolumn{4}{|c|}{ Cronbach's Alpha $=, 814$} \\
\hline Aday hakkında televizyonlardan edindiğim fikir & & & & 821 \\
\hline Adayın televizyon tartışma programlarında gösterdiği performans & & & & ,808 \\
\hline Aday hakkında gazetelerden edindiğim fikir & & & &, 762 \\
\hline Adayın hitabet yeteneği & & & & ,611 \\
\hline
\end{tabular}

2019 Yerel Seçimlerinde seçmen tercihleri üzerinde adayların imajlarından hangilerinin ne derece etkili olduğunu anlamaya yönelik olarak dört faktörden ve beşli Likert ölçeğinden oluşan sorular hazırlanmış olup, bu sorulara katılımcıların verdikleri cevaplar Tablo 10'da yer almaktadır. Bu bağlamda seçmenin sosyal çevresinin ve ailesinin aday ile ilgili olan düșüncelerinin seçmen kararındaki etkisi anlaşılmaya çalışılmıștır. Çevresel Eğilim olarak isimlendirilen bu faktörde en büyük yüke sahip olanlar sırasıyla "Adayı, görüşüne önem verdiğim insanların desteklemesi" , "adayı, yakın çevremde yer alan insanların destekliyor olması" ve "adayı ailemin de desteklemesi" cevapları ön sırada yer almaktadır. Ayrıca "Adayın kamuoyu araştırmalarına göre önde olması", "Adaya daha önce oy vermiş olmam" ve "Adayın seçimi kazanma ihtimali" de ortalamanın üstünde bir yüke sahiptir. Çevresel eğilim faktörünü Cronbach's Alpha değeri =,866 ile diğer faktörlerden de yukarıda bir değere sahiptir. 
Araştırmada kullanılan ikinci faktör ise =,854 Cronbach's Alpha değerine sahip olan Adayın Karakteristiği ve Partisi'dir. Bu faktörde katılımcıların cevapları doğrultusunda en büyük yük "Adayın iş bitiricilik ve girişkenlik yeteneği" sorusunda toplanmıştır. Sırasıyla "Adayın yolsuzlukları önleme gücü ve etkisi", "Adayın gündemdeki sorunlar hakkında bir proje üretiyor olması", "Adayın şehrin sorunları hakkındaki bilgisi ve ilgisi" ve "Adayın dürüst bir kişiliğe sahip olması" sorularına verilen cevaplar takip etmektedir.

Siyasi Konjonktür ve Başarı araştırmada kullanılan ölçeğe ait üçüncü faktör olup, bu faktörün Cronbach's Alpha değeri =,852'dir. 2019 Yerel Seçimleri esnasında görevde olan "Hükümeti başarılı görme"leri ve "Adayın hükümetle uyumlu olması gerektiği yönünde yapılan açıklama”, "Adayın halen aday olduğu görevi icra ediyor olması", "Adayın hükümet ve bürokrasi çevresiyle iyi ilişkilerde bulunması" ve "Adayın mensubu olduğu partinin iktidarda olması" gibi sorular yer almaktadır. Katılımcıların verdikleri cevaplara ilişkin oluşan sonuçlar yukarıda büyükten küçüğe doğru sıralanmıștır. Dolayısıyla seçmenlerin adayın hükümetle olan ilişkileri önemsediği görülmektedir.

Araştırmada kullanılan ölçekte yer alan dördüncü faktör ise adayın iletişim becerileri ile medyayla olan ilişkilerinin seçmenlerin kararı üzerindeki etkisini ölçmek amacıyla oluşturulmuş olan Medya ve İletişim faktörüdür. Faktörün Cronbach's Alpha değeri $=, 814$ 'tür. Bu faktörde ise büyükten küçüğe doğru yükler sırasıyla "Aday hakkında televizyonlardan edindiğim fikir", "Adayın televizyon tartışma programlarında gösterdiği performans", "Aday hakkında gazetelerden edindiğim fikir" ve "Adayın hitabet yeteneği" olarak șekillenmiștir.

Tablo 11. Faktör Gruplarıly Cinsiyetler Arasındaki Farklılaşma

\begin{tabular}{|c|c|c|c|c|c|c|}
\hline Faktörler & Cinsiyet & $\mathbf{N}$ & Ortalama & Std. Sapma & $\mathbf{T}$ & Sig \\
\hline \multirow{2}{*}{ Çevresel Eğilim } & Erkek & 326 & 2,7889 & 1,05587 & \multirow{2}{*}{,271 } & \multirow{2}{*}{, 768} \\
\hline & Kadın & 211 & 2,7630 & 1,10993 & & \\
\hline \multirow{2}{*}{ Adayın Karakteristiği ve Partisi } & Erkek & 326 & 3,7012 & 1,00946 & \multirow{2}{*}{,- 035} & \multirow{2}{*}{,972 } \\
\hline & Kadın & 211 & 3,7043 & ,96714 & & \\
\hline \multirow{2}{*}{ Siyasi Konjonktür ve Başarı } & Erkek & 325 & 2,9589 & 1,09955 & \multirow[t]{2}{*}{1,083} & \multirow{2}{*}{,279 } \\
\hline & Kadın & 211 & 3,0569 & 1,07924 & & \\
\hline \multirow{2}{*}{ Medya Ve İletişim } & Erkek & 326 & 3,1656 & ,98790 & \multirow{2}{*}{1,628} & \multirow{2}{*}{, 104} \\
\hline & Kadın & 211 & 3,3152 & 1,11439 & & \\
\hline
\end{tabular}

Çevresel Eğilim, Adayın Karakteristiği ve Partisi, Siyasi Konjonktür ve Başarı ile Medya ve İletişim faktörlerinin hepsinin cinsiyete göre ortalamaları arasında büyük bir istatistiki fark bulunmamakla birlikte hepsinin sig. değerleri, 05'ten büyük olduğu için anlamlı bir farklılığa rastlanılmamıştır.

Tablo 12. Faktörlerin Demografik Değişkenlere Göre Farklılaşmaları

\begin{tabular}{|l|c|c|c|c|c|c|c|c|}
\hline \multirow{2}{*}{ Faktörler } & \multicolumn{2}{|c|}{ YAŞ } & \multicolumn{2}{c|}{ MESLEK } & \multicolumn{2}{c|}{ GELiR } & \multicolumn{2}{c|}{ EĞitiM } \\
\cline { 2 - 9 } & F & Sig & F & Sig & F & Sig & F & Sig \\
\hline Çevresel Eğilim & 2,725 &, 029 & 1,641 &, 110 & 3,788 &, 005 & 3,185 &, 004 \\
\hline Adayın Karakteristiği ve Partisi &, 115 &, 977 & 1,272 &, 256 & 6,180 &, 000 &, 548 &, 771 \\
\hline Siyasi Konjonktür ve Başarı &, 680 &, 606 & 1,343 &, 220 & 2,689 &, 031 & 1,726 &, 113 \\
\hline Medya ve İletişim &, 573 &, 682 &, 847 &, 562 &, 917 &, 917 & 1,209 &, 300 \\
\hline
\end{tabular}

Tablo 12'de faktörler ile demografik değişskenler arasındaki anlamlılık düzeylerine ilişkin verilere yer verilmiştir. İlk olarak katılımcıların yaşlarının faktörlerle olan anlamlılıklarına bakılmıştır. Yapılan incelemede Çevresel Eğilim faktörü ile katılımcıların 
yaşları sig. değeri, 05’ten küçük olduğu için anlamlı farklılık olduğu belirlenmiştir. Yaş faktörü ile Adayın Karakteristiği ve Partisi, Siyasi Konjonktür ve Başarı ile Medya ve İletişim faktörleri arasında ise sig. değerlerinin, 05 'ten büyük olmasından ötürü anlamlı bir farklılık görülmemiştir.

Araştırmaya katılan seçmenlerin meslekleriyle faktörler arasındaki anlamlılık düzeyi de yine bu tabloda incelenmiştir. Elde edilen sonuçlarda Çevresel Eğilim, Adayın Karakteristiği ve Partisi, Siyasi Konjonktür ve Başarı ile Medya ve İletişim faktörlerinin tamamında sig. ,05’ten büyük olması nedeniyle anlamlı bir farklılık bulunmamıştır.

Tablo 12'de ele alınan bir diğer konuda katılımcıların gelirlerinin faktörlerle olan ilişkidir. Yapılan incelemede katılımcıların gelir düzeylerinin sig. değerleri, 05'ten küçük olan Çevresel Eğilim faktörü ile Adayın Karakteristiği ve Partisi faktörü arasında anlamlı bir farklılık olduğu belirlenmiştir. Ancak Siyasi Konjonktür ve Başarı ile Medya ve İletişim faktörleri ile katılımcıların gelirleri arasında ise sig. değerlerinin, 05'ten büyük olması nedeniyle anlamlı bir farklılığa rastlanılmamıştır.

Katılımcıların eğitim düzeyleri ile faktörler arasında yapılan incelemede yine Tablo 12'de değerlendirilmiştir. Yapılan değerlendirme sonucunda katılımcıların eğitim düzeyleri ile adayın çevresel eğilim faktörü arasındaki sig. değerinin, 05'ten küçük olması nedeniyle anlamlı bir farklılık görülmüştür. Adayın Karakteristiği ve Partisi, Siyasi Konjonktür ve Başarı ile Medya ve İletişim faktörlerinde ise sig. değerinin, 05'ten büyük olması nedeniyle anlamlı bir farklılık saptanmamıştır.

\section{Sonuç ve Tartışma}

Seçmenlerin oy tercihlerinin belirlenmesine yönelik olarak Sivas ilinde 31 Mart 2019 Yerel Seçimleri özelinde yapılan bu çalışmada Balcı ve Damlapınar (2014) tarafından 29 Mart 2009 tarihinde yapılan yerel seçimler için kullanılan ölçek kullanılmıştır. Araştırmanın amacı yerel seçimlerde seçmenlerin tercihlerini belirlerken hangi faktörleri göz önüne aldıkları ve adayın imajının bu karar sürecinde ne derece etkili olduğunun belirlenmesidir.

Araştırmada, katılımcıların karar süreçlerinde birden fazla aracın etkisinin bulunduğu ancak bu araçlar içerisinde ise internet ve sosyal medyanın etkisinin diğerlerine oranla daha fazla olduğu görülmektedir. Ayrıca sosyal çevre ve ailenin seçmen tercih sürecinde etkisinin baskın olduğu sonucuna ulașılmıștır. Seçmen tercihlerinde gazete ve radyonun etkisinin ise daha önceki yıllarda yapılan araştırmalara oranla düşüş gösterdiği ya da kısıtlı kaldığı rahatlıkla söylenebilmektedir.

Yine çalışmada seçmenlerin genellikle sosyal çevrelerinden ve ailesinin aday ile ilgili olan düşüncelerinden etkilendiği görülmektedir. Seçmenlerin adayların karakteristik özellikleri, iş bitiricilik, ev girişkenlik yeteneği, gündemdeki sorunlar hakkındaki çözüm önerileri, şehir hakkında projeleri gibi hem adayın kişisel özelliklerine hem de iş yaşantısına ait bireysel özelliklerine odaklandıkları saptanmıştır. Adayın hükümetle olan ilişkisinin, bürokratik çevresinin hatta hükümetin başarısının dahi seçmenlerin kararı üzerinde etkili olduğu belirlenmiştir. Bilhassa araștırmaya katılan seçmenler adayın geçmiş yaşantısından itibaren başarılarına da odaklanmaktadır. Adayların kitle iletişim araçlarındaki konuşmaları, tartışma programlarındaki hal ve tutumlarının da seçmen tercihleri üzerinde etkili olduğu sonucuna çalışmada ulaşılmıştır. 
Araştırmada elde edilen bir diğer sonuçta, katılımcıların aile ve sosyal çevrelerinin etkisi altında kararlarını belirleme düzeylerinin yaşlara göre değiştiğidir. Diğer bir deyişle katılımcıların yaşlarındaki değişim onların karar verme süreçlerinde doğrudan etkilidir. Buna ek olarak seçmenlerin gelirlerindeki değişimde yine adayın karakteristik özelliklerine ve aday olduğu siyasal partiye olan tutumlarına etki etmektedir. Seçmenlerin gelirlerindeki değişim onların çevresel faktörlerin etkisi altında karar verme süreçlerini de direkt olarak etkilemektedir.

2019 Yerel Seçimleri özelinde yapılan bu çalışmaya katılan seçmenlerin eğitim düzeylerindeki değișim onların karar süreçlerinde etkili bir diğer etken olarak öne çıkmaktadır. Özellikle araştırmaya katılan seçmenlerin eğitim düzeylerinin onların çevrelerinin etkisi altında kalma süreçlerini etkileyen bir faktör olarak öne çıkmaktadır.

Sonuç olarak 31 Mart 2019 tarihinde Sivas ili özelinde gerçekleştirilen bu çalışmada ulaşılan sonuçlar katılımcıların verdikleri cevaplar üzerinden elde edilen verilerin yorumlanmasıyla sağlanmıştır. Daha önceki yıllarda seçmen tercihleri üzerine yapılan çalışmalarda elde edilen sonuçlarla bu çalışmada ulaşılan sonuçlar paralellik gösterse dahi, başta geleneksel kitle iletişim araçlarının, sonrasında ise sosyal medya ve internetin seçmen tercihleri üzerindeki etkisinin farklı olduğu görülmüştür.

Bilhassa bundan sonraki seçimlerde yapılacak olan çalışmalarda sosyal medyanın etkisine yönelik soruların artırılması faydalı olacaktır. Adayların sosyal medya ve internet üzerinden yürütecekleri çalışmalar, orada kendileri hakkında seçmenlere sunacakları bilgiler, onların başarısını doğrudan etkileyebilecektir. Bu nedenle 2008 ABD Başkanlık Seçimlerinden beri seçim kampanyalarında ayrı bir yere sahip olan sosyal medya ve internet gelecek seçimlerde doğrudan odak noktası olacaktır. Özellikle yerel televizyonların sayısının azaldığı günümüzde, geleneksel kitle iletişim araçlarının yerini bu mecraların alması da doğal bir sonuç olarak görülmektedir.

Yerel seçimlerin hükümetin ve ülkenin başarısından etkilendiği sonucuna ek olarak adayların, aday olacakları siyasal partilerin iktidarda olması kadar başarılı olması da önemlidir. Ayrıca adayların seçmen gözündeki imajlarının da etkili olduğu unutulmamalıdır.

\section{Etik Kurul İzni}

Sivas Cumhuriyet Üniversitesi Bilimsel Araştırma ve Yayın Etiği Sosyal ve Beşeri Bilimler Kurulu 28/09/2020 tarih ve 12 no'lu toplantısında alınan karar çerçevesinde çalışma etik açıdan bir sakınca içermemektedir.

\section{Kaynakça}

Aydın, K., \& Özbek, V. (2004). Ailenin seçmen davranışları üzerindeki etkisi. Kocaeli Ünivresitesi Sosyal Bilimler Enstitüsü Dergisi, 144-167.

Balcı, Ş. (2003). Politik kampanyalarda imaj. Selçuk Üniversitesi Sosyal Bilimler Enstitüsü Dergisi, 153-162.

Baltacı, C., \& Eke, E. (2012). Siyasal propaganda araçlarının seçmen davranışı üzerindeki etkisine yönelik seçmen algısı: Isparta örnek olayı. Uluslararası Alanya Isşletme Fakültesi Dergisi, 115-126.

Baudrillard, J. (2006). Sessiz yığınların gölgesinde toplumsalın sökümü. (O. Adanır, Çev.) İstanbul: DoğuBatı. 
Bülbül, A. R. (2004). Halkla ilişkiler. Ankara: Nobel Yayın Dağıtım A.Ş.

Çobanoğlu, Ş. (2007). Suskunluk sarmalı ve siyasal iletişim. İstanbul: Fide Yayınları.

Çukurçayır, M. A. (2012). Siyasal katılma ve yerel demokrasi. Konya: Çizgi Kİtapevi.

Damlapınar , Z., \& Balcı , Ş. (2014). Seçimler, adaylar, imajlar. Konya: Literatürk Academy.

Doğan , A., \& Göker, G. (2010). Yerel seçimlerde seçmen tercihi: 29 Mart yerel seçimleri Elazığ seçmeni örneği. Eskişehir Osmangazi Üniversitesi İIBF Dergisi, 159-187.

Doğan, A. (2017). Türkiye'de siyasal iletişim ve siyasal davranış. Ankara: Nobel Yayıncılık.

Dursun, D. (2016). Siyaset bilmi. İstanbul: Beta Yayım Dağıtım A.Ş.

Dursunoğlu, İ. (2017). Sosyal medya ve siyasal davranış ilişkisi. Süleyman Demirel Üniversitesi İktisadir ve İdari Bilimler Dergisi, 1579-1585.

Gencer, Z. T. (2020). Kurumlarda sürekliliğin sağlanması açısından kurumsal iletişimin rolü. Z. T. Gencer içinde, Kurumsal İletişimin El Kitabı (s. 349-363). Konya: Eğitim Yayınevi.

Hacker, K. l., Walter R. Zakahi, M. J., \& McQuitty, S. (2000). Components of candidate Images: Statistical analysis of the issue-persone dichotomy in the presidential campaign of 1996. Communication Monographs, 227-238.

Heywood, A. (2018). Siyaset teorisine giriş. (H. M. Köse, Çev.) İstanbul: Küre Yayınları.

Kalender, A. (2000). Siyasal iletişim seçme ve ikna stratejileri. Konya: Çizgi Yayınevi.

Kaya, K. (2011). Akademisyenlerin gözüyle Türkiye'de din-siyaset ilişkisi (Süleyman Demirel Üniversitesi örneği). Isparta: Fakülte Kitapevi.

Kışlalı, A. T. (2018). Siyaset bilimi. İstanbul: İmge Yayını.

Köni, H. S. (1982). Genel sistem kuramı ve uluslararası sisyasal örgütlerde karar verme. Ankara: Ankara İktisadi ve Ticari İlimler Akademisi.

Lilleker, D. G. (2006). Key concepts in political communication. London: Great Briain.

Mutlu, E. (2008). İletişim sözlüğü. Ankara: Ayraç Kitap + Evi.

Peltekoğlu, F. B. (2014). Halkla ilişkiler nedir? İstanbul: Beta Basım A.Ş.

Russell, B. (2014). Íktidar. İstanbul: Cem Yayınevi.

TDK. (2009). Türkçe sözlük. (Ş. H. Akalın, Dü.) Ankara: Atatürk Kültür, Dil ve Tarih Yüksek Kurumu Türk Dil Kurumu Yayınlar.

Tokgöz, O. (2010). Seçimler, siyasal reklamlar ve siyasal iletişim.

Toprak, Z. (2011). Yerel yönetimlerde başkanın politik lider rolü. İstanbul Üniversitesi Hukuk Fakültesi Mecmuası, 299-316.

Türkkahraman, M. (2004). Günümüzün büyüsü imaj ve gerçek hayat. Sosyoloji Konferansları (s. 1-14). İstanbul: İstanbul Üniversitesi Yayınları.

Ural, M. (2002, Kasım 02). Kampanyaların anatomisi. Radikal.

Williams, R. (2007). Anahtar sözcükler. İstanbul: İletişim Yayınları. 


\title{
Effective Factors on Determining the Voting Preferences of Voters and the Effect of Candidate Image on this Process: 31 March 2019 Sivas Local Elections Example
}

\author{
Onur Taydaş (Asst. Prof. Dr.)
}

\section{Extended Abstract}

Politics is considered as a social issue among people. If we look at the example of Robinson Crouse, who lives on a deserted island alone, there is no second will, other than himself, to prevent or support him from making or holding back from his decision until the arrival of Friday. Robinson Crouse, who takes the decisions he wants and puts them into practice as quickly as he wishes, is unaware of politics and does not need politics. However, it should be known that in modern societies, no one can stay away from politics, based on the fact that one cannot be a Robinson Crouse. For this reason, politics is a power struggle that includes the meanings of maintaining/maintaining public order in addition to the management of society. Perhaps the main reason why politics is called a power struggle is the conflict of opposites in social life and politics trying to combine these oppositions at a certain point.

In the process of solving problems and reconciling oppositions, all responsibility falls on the actors of the political sphere. Leaders, pressure groups, political parties, voters, governments, non-governmental organizations, etc. many different groups or persons are among these actors. All these actors mentioned are effective in determining political power. In this sense, politics can be considered as a communication process between political actors. The main problem here is the question of whom all these actors will cluster on the road to power and afterward. Because in representative democracies, the people have to vote for a political party leader or a candidate to rule them. At this point, various studies have been conducted to understand how voters make their decisions while performing the act of voting as a civic duty, and three different models have been developed. The first of these is the rational (economic) approach, which states that the voters know their interests well and they turn to the candidate or leader that they think will best serve these interests. The second is the approach that prioritizes the attitudes of the voters towards the political party, their perception of political life, and their attachment to a party, known as psychological or party identification. The sociological approach sees communication and interaction between small groups as an important element of the decision-making process. However, another factor that is as effective in voter decisions as the approaches mentioned above is the images of the candidates. Like the main feature of all other image studies, the image of the candidate is formed as a result of a certain accumulation. This accumulation comes into being as a reflection of the culture in which people live. The candidate image is an extrovert presentation. It is a structure in memory. Nevertheless, the process of determining and using the image by politicians was the first time that the public began to move away from politics, and secondly, politics turned towards the media and the celebrities there. It is a fact that politicians started to use the image in this sense to create a psychological effect on the public and to take place in the media.

The data collection process of this study, which was conducted to understand how effective the image of the candidate is in determining the preferences of the voters, who 
are the determinants of the governments in modern democratic societies, was carried out between April 5 and April 30, 2019, in Sivas. In the local elections of 31 March 2019, individuals who have the right to vote within the city center of Sivas were determined as the main body of the study. The sample selection in the study was done by the simple random sampling method. In this context, 537 questionnaires were applied face to face with randomly selected individuals who wanted to participate in the study within the borders of Sivas city center. Besides, while investigating the effect of candidate image on voter preferences in the 2019 Local Elections, the significance levels of the demographic variables used according to the factors related to the candidate image were also investigated.

In the study, it is seen that more than one tool has an effect on the decision-making processes of the participants, but within these tools, the effect of the internet and social media is higher than the others. Besides, it was concluded that the influence of the social environment and family in the voter selection process is dominant. It can be easily said that the effect of newspapers and radio on voter preferences has decreased or remained limited compared to previous studies. Again, in the study, it is seen that voters are generally influenced by their social environment and family's thoughts about the candidate. It was determined that the voters focused on both the personal characteristics of the candidates and the individual characteristics of their business life, which meet the characteristics of the candidates such as practicality, home assertiveness, solution proposals for current problems, and projects about the city. It has been determined that the candidates' relationship with the government, their bureaucratic circle, and even the success of the government have an impact on the voters' decision. It was concluded that the speeches of the candidates in the mass media, their stance, and attitude in the debate programs also affect voter preferences.

Keywords: Communication, Candidate Image, Local Elections, Voter Behavior, Political Communication.

Bu makale intihal tespit yazılımlarıyla taranmıştır. Intihal tespit edilmemiş̧tir.

This article has been scanned by plagiarism detection softwares. No plagiarism detected.

Bu çalışmada "Yükseköğretim Kurumları Bilimsel Araştırma ve Yayın Etiği Yönergesi" kapsamında uyulması belirtilen kurallara uyulmuştur.

In this study, the rules stated in the "Higher Education Institutions Scientific Research and Publication Ethics Directive" were followed. 